\title{
Assessment of breast cancer risk among Iraqi women in 2019
}

\author{
Hashim Talib Hashim', Mustafa Ahmed Ramadhan', Kabas Monther Theban', John Bchara2*, \\ Ahed El-Abed-El-Rassoul ${ }^{3}$ and Jaffer Shah ${ }^{4}$
}

\begin{abstract}
Background: Breast cancer is one of the most common cancers among women worldwide and the leading cause of death among Iraqi women. Breast cancer cases in Iraq were found to have increased from 26.6/100,000 in 2000 to $31.5 / 100,000$ in 2009. The present study aims to assess the established risk factors of breast cancer among Iraqi women and to highlight strategies that can aid in reducing the incidence.
\end{abstract}

Methods: 1093 Iraqi females were enrolled in this cross-sectional study by purposive sampling methods. Data collection occurred from July 2019 to September 2019. 1500 women participated in the study, and 407 women were ultimately excluded. The questionnaire was conducted as a self-administrated form in an online survey. Ethical approval was obtained from the College of Medicine in the University of Baghdad. The Gail Model risk was calculated for each woman by the Breast Cancer Risk Assessment Tool (BCRAT), an interactive model developed by Mitchell Gail that was designed to estimate a woman's absolute risk of developing breast cancer in the upcoming five years of her life and in her lifetime.

Results: The ages of the participants ranged from 35 to 84 years old. The mean 5 -year risk of breast cancer was found to be 1.3 , with $75.3 \%$ of women at low risk and $24.7 \%$ of women at high risk. The mean lifetime risk of breast cancer was found to be 13.4 , with $64.7 \%$ of women at low risk, $30.3 \%$ at moderate risk, and $5.0 \%$ at high risk. The results show that geographically Baghdad presented the highest 5-year risk, followed by Dhi Qar, Maysan, and Nineveh. However, the highest lifetime risk was found in Najaf, followed by Dhi Qar, Baghdad, and Nineveh, successively.

Conclusion: Breast cancer is a wide-spreading problem in the world and particularly in Iraq, with Gail Model estimations of high risk in several governorates. Prevention programs need to be implemented and awareness campaigns organized in order to highlight the importance of early detection and treatment.

Keywords: Breast cancer, Gail Model, BCRAT, Assessment, 5 years'risk, Lifetime risk

\section{Introduction}

Breast cancer is one of the most common cancers among women worldwide, and the second leading cause of death in women after lung cancer [1]. Each year, nearly 2.09 million women are diagnosed with breast cancer and 627000 die from the disease [2]. In Iraq, breast cancer is

\footnotetext{
*Correspondence: johnbshara@gmail.com

2 Faculty of Medicine, Tishreen University, Latakia, Syria

Full list of author information is available at the end of the article
}

the most common cancer, and the leading cause of death among Iraqi women [3]. Breast cancer-related cases in Iraq were found to have increased from 26.6/100,000 in 2000 to $31.5 / 100,000$ in 2009 [4]. Moreover, the agerelated incidence rate in Iraq was found to be greater than that in Turkey, Iran, Saudi Arabia, and Bahrain, while less than that in Jordan and Kuwait [5].

Breast cancer risk factors are related to the female's age, parity, family history of breast cancer, especially firstdegree relatives, radiation exposure, smoking, and the 
genetic factors of BRCA1 and BRCA 2 gene mutations [6]. Awareness of the symptoms and early screening are important methods of reducing the risks associated with breast cancer. The American Cancer Society has developed guidelines for the prevention and early detection of breast cancer, where women with moderate-to-high risks of developing breast cancer are recommended to undergo regular screening mammography tests starting at the age of 45 years $[7,8]$.

There are many risk assessments models-such as the Gail Model, Claus Model, BRCAPRO Model, and Cuzick-Tyrer Model-that are used as tools to determine a female's breast cancer-associated risk [9-12]. The Gail Model is the most widely used risk model, as it calculates both a 5-year risk and a lifetime risk of breast cancer. This risk is measured based on the woman's age, age of menarche, age of first birth, family history, and number of biopsies conducted [11, 13]. The Gail Model has been validated in many countries and is used extensively in many studies as a tool to assess breast cancer-related risk [13].

This study aims to assess the established risk factors of breast cancer among Iraqi women and to highlight the benefits of certain strategies that can aid in controlling its incidence.

\section{Materials and methods}

\section{The aim, design and setting of the study}

Our study is a cross-sectional study, enrolling 1093 Iraqi females, out of an estimated population of 41 million, by purposive sampling methods from all of Iraq's 18 governorates [14].

\section{The characteristics of participants or description \\ of materials}

The purpose of this study was explained to each participant before acquiring their consent to participate, and those who refused to participate were excluded. Women who had previously received chest radiation therapy for the treatment of Hodgkin Lymphoma were also excluded. Data collection occurred from July 2019 to September 2019, with 1500 women participating in the study from all of Iraq's cities. 407 women were excluded for the following reasons: 150 refused to participate, 169 had already been diagnosed with breast cancer, and 88 had received chest radiation for the treatment of Hodgkin Lymphoma. As a result, only 1093 women were included the study.

The Gail Model was implemented to assess the risk of breast cancer among the study records. This model is known by the National Cancer Institute as BCRAT (Breast Cancer Risk Assessment Tool).
The questionnaire was conducted as a self-administrated form in an online survey, as well as face-toface interviewing and a paper survey. A pilot study of 73 participants was first performed in order to test the validity and reliability of the Arabic version of the questionnaire. It was tested for validity by sending a translation of the questionnaire to six experts in the specialty-three from Baghdad Medical College, two from Dhi Qar Medical College, and one from Basra Medical College-that all accepted the format upon revision. The questionnaire was further tested for reliability by assessing the 5 -year risk of the first 73 women upon administering the survey, and then repeating the survey with the same group at a later point of time to compare the predicted risk for each. The overall internal reliability (Cronbach's $\alpha=0.87$ ) was high.

A structured questionnaire was used to collect sociodemographic data from participants, including number of children, occupation, educational level, monthly income, use of contraceptives, breast feeding, smoking, and physical activity. In addition, details were collected regarding risk factors for breast cancer, such as age, age at menarche, age at the $1^{\text {st }}$ live birth, number of previous breast biopsies, presence of atypical hyperplasia in any previous breast biopsy specimen, and history of breast cancer among the participant's first-degree relatives (mother, daughter and sister). Participant race was also collected on the questionnaire, with three options relating to the three main races of Iraqi women (Arabic, Kurdish, and Turkmen).

Ethical approval was obtained from the College of Medicine in the University of Baghdad in order to conduct the study.

\section{The statistical analysis}

A Student's t-test was used to check for any significant differences between the mean values of two continuous variables. Multiple linear regression models were also used to estimate the effect of each variable on the 5 -year and lifetime breast cancer risk. The level $P<0.05$ was considered as the cutoff value for significance.

The Gail Model risk for each woman was calculated by Breast Cancer Risk Assessment Tool (BCRAT), an interactive model developed by Mitchell Gail for estimating a woman's absolute risk of developing invasive breast cancer in both the upcoming five years of her life and her entire lifetime.

The Gail Model calculates the probability of a woman at age $\alpha$ who has age-related relative risk $r(t)$. The woman may develop breast cancer by age $\alpha+\mathbf{\tau}$ according to the following equation: 


$$
\boldsymbol{p}\{\boldsymbol{a} . \boldsymbol{\tau} . \boldsymbol{r}(\boldsymbol{t})\}=\int_{a}^{a+\tau} h_{1}(\boldsymbol{t}) r(\boldsymbol{t}) e^{-\int_{a}^{\tau} h_{1(u) r(u) d u}}\left\{S_{2}(\boldsymbol{t}) / S_{2}(\boldsymbol{a})\right\} d t
$$

where $\boldsymbol{h}_{1}(\boldsymbol{t})$ is the baseline age-specific hazard of developing breast cancer and $\boldsymbol{S}_{2}(\boldsymbol{t})=\boldsymbol{e x p}\left\{-\int_{0}^{1} \boldsymbol{h}_{2}(\boldsymbol{u}) \boldsymbol{d u}\right\}$ is the probability of surviving competing risks up to age $t$ [15].

The baseline age-specific hazard rates were obtained from the average ("composite") age-specific breast cancer rates $\boldsymbol{h}^{*}{ }_{1}(\boldsymbol{t})$ using $\boldsymbol{h}_{\mathbf{1}}(\boldsymbol{t})=\boldsymbol{h}^{*}{ }_{1}(\boldsymbol{t}) \boldsymbol{F}(\boldsymbol{t})$, where $\boldsymbol{F}(\boldsymbol{t})$ is 1 minus the attributable risk fraction for age $\mathrm{t}$ [16].

Statistical Package for the Social Science (SPSS) version 25 and Statistical Analysis Software (SAS) version 16 were used in calculations and significance testing.

Using the Gail Model as a golden standard, a woman with a probability of less than $1.66 \%$ of developing breast cancer in 5 years is considered to be at low risk. Conversely, a woman with a probability of more than $1.66 \%$ is classified as high risk and is recommended to undergo intensive screening by annual mammography and clinical breast examination every 6 to 12 months [15].

Regarding lifetime risk, a woman with a probability of less than $15 \%$ of developing breast cancer is considered to be at low risk, a woman with a probability of $15-30 \%$ is considered to be at moderate risk, and a woman with a probability of more than $30 \%$ is considered to be at high risk. Lifetime risk is defined as the risk of developing breast cancer up to 90 years of age [15].

\section{Results}

The ages of the participants ranged from 35 to 84 years old, with a mean of 46.4 and a standard deviation of 9.5. The characteristics of the study participants are further clarified in Table 1.

Table 2 shows the distribution of the participants throughout the Iraqi governorates.

The mean of the 5-year risk was found to be 1.3 with a standard deviation of 1.0, and the mean of the lifetime risk was 13.4 with a standard deviation of 6.8. Table 3 lists the frequencies of the risks among the participants.

Table 4 shows the 5-year risk and the lifetime risk assessment measured using the Gail Model for the characteristics of study participants.

Table 5 shows the general linear regression model analysis predictors for both the 5-year and lifetime risks of developing breast cancer in Iraqi women between 35 and 85 years of age. The identified predictors for breast cancer in women were listed as age, age at menarche, age of first birth, number of first-degree relatives with breast cancer, race, number of biopsies, age of menopause,
Table 1 Characteristics of study participants

\begin{tabular}{|c|c|c|}
\hline & Frequency & Percentage \\
\hline \multicolumn{3}{|c|}{ 1. Are your parents blood relatives? } \\
\hline Yes & 473 & 43.3 \\
\hline No & 614 & 56.2 \\
\hline Unknown & 6 & 0.5 \\
\hline \multicolumn{3}{|l|}{ 2. Marital status } \\
\hline Yes & 1006 & 92 \\
\hline No & 87 & 8 \\
\hline \multicolumn{3}{|l|}{ 3. Educational level } \\
\hline Illiterate & 211 & 19.3 \\
\hline Primary & 252 & 23.1 \\
\hline Secondary & 293 & 26.8 \\
\hline University & 337 & 30.8 \\
\hline \multicolumn{3}{|l|}{ 4. Number of children } \\
\hline No children & 131 & 12 \\
\hline $1-2$ children & 162 & 14.8 \\
\hline $3-5$ children & 476 & 43.5 \\
\hline More than 5 & 324 & 29.6 \\
\hline \multicolumn{3}{|l|}{ 5. Age at first live birth } \\
\hline No birth & 130 & 11.9 \\
\hline Less than 20 years & 346 & 31.7 \\
\hline 20-24 years & 351 & 32.1 \\
\hline $25-29$ years & 195 & 17.8 \\
\hline $30-39$ years & 69 & 6.3 \\
\hline More than 40 years & 2 & 0.2 \\
\hline \multicolumn{3}{|l|}{ 6. Breast feeding } \\
\hline Yes & 846 & 77.4 \\
\hline No & 247 & 22.6 \\
\hline \multicolumn{3}{|l|}{ 7. Use of contraceptives } \\
\hline Yes & 544 & 49.8 \\
\hline No & 549 & 50.2 \\
\hline \multicolumn{3}{|c|}{ 8. Age of menarche (first menstrual cycle) } \\
\hline $7-11$ years & 113 & 10.3 \\
\hline $12-13$ years & 671 & 61.4 \\
\hline More than 13 years & 309 & 28.3 \\
\hline \multicolumn{3}{|c|}{ 9. Premenopausal of postmenopausal } \\
\hline Premenopausal & 741 & 67.8 \\
\hline Postmenopausal & 352 & 32.2 \\
\hline \multicolumn{3}{|l|}{ 10. Race } \\
\hline Arabic & 881 & 80.6 \\
\hline Kurdish & 137 & 12.5 \\
\hline Turkmen & 75 & 6.9 \\
\hline \multicolumn{3}{|l|}{ 11. Monthly income to family } \\
\hline Low (Less than 250 IQD) & 224 & 20.5 \\
\hline Moderate (250-Million IQD) & 615 & 56.3 \\
\hline High (More than Million IQD) & 254 & 23.2 \\
\hline \multicolumn{3}{|c|}{ 12. Smoking (including shisha and vape) } \\
\hline Yes & 57 & 5.2 \\
\hline No & 1036 & 94.8 \\
\hline 13. Physical activity & & \\
\hline
\end{tabular}


Table 1 (continued)

\begin{tabular}{lcl}
\hline & Frequency & Percentage \\
\hline Never & 648 & 59.3 \\
Once weekly & 188 & 17.2 \\
Twice weekly & 116 & 10.6 \\
More than twice weekly & 141 & 12.9 \\
14. Number of biopsies & & \\
No Biopsy & 1058 & 96.8 \\
One Biopsy (Without Hyperplasia) & 35 & 3.2 \\
15. Number of first-degree relatives with breast cancer & \\
No one & 907 & 83 \\
One relative & 120 & 11 \\
More than one relative & 66 & 6 \\
16. Occupation & & \\
Housewife & 736 & 67.3 \\
Others & 357 & 32.7 \\
\hline
\end{tabular}

contraceptives usage, monthly income, smoking, and

Table 2 The governorates of the participants

\begin{tabular}{lcl}
\hline & Frequency & Percentage \\
\hline Anbar & 46 & 4.2 \\
Babil & 45 & 4.1 \\
Baghdad & 191 & 17.5 \\
Basra & 97 & 8.9 \\
Dhi Qar & 75 & 6.9 \\
Diyala & 47 & 4.3 \\
Dohuk & 44 & 4 \\
Erbil & 53 & 4.8 \\
Karbala & 33 & 3 \\
Kirkuk & 58 & 5.3 \\
Maysan & 52 & 4.8 \\
Muthanna & 40 & 3.7 \\
Najaf & 62 & 5.7 \\
Nineveh & 60 & 5.5 \\
Qadisiyyah & 53 & 4.8 \\
Saladin & 51 & 4.7 \\
Sulaymaniyah & 37 & 3.4 \\
Wasit & 49 & 4.5 \\
Total & 1093 & 100 \\
\hline
\end{tabular}

physical activity. Variables with $(P<0.001)$ were considered significant and strong predictors for breast cancer.

Globally reported Gail's breast cancer risk assessments are classified in Table 6. The Gail Model overestimates risk in most of the studies outside the United States, due to the fact that the risk factors and incidence rates of breast cancer vary greatly across different races and countries.
Table 3 The 5-year risk frequencies

\begin{tabular}{lcl}
\hline & Frequency & Percentage \\
\hline Low & 823 & 75.3 \\
High & 270 & 24.7 \\
Total & 1093 & 100 \\
The lifetime risk frequencies & & \\
Low & 707 & 64.7 \\
Moderate & 331 & 30.3 \\
High & 55 & 5.0 \\
Total & 1093 & 100.0 \\
\hline
\end{tabular}

Figure 1 shows the distribution of both risks on the governorates. It shows that Baghdad presents the highest 5-year risk, followed by Dhi Qar, Maysan, and Nineveh, in that order. Najaf presents the highest lifetime risk, followed by Dhi Qar, Baghdad, and Nineveh successively.

\section{Discussion}

We found that the 5-year risk and lifetime risk of developing breast cancer for women in Iraq is 1.3 and 13.4, respectively. These figures are higher than those of a previous study performed in 2016 in Baghdad, which found a 5-year risk and lifetime risk of 0.95 and 11.3, respectively [23]. (For Baghdad only, we found 5-year and lifetime risk of 1.3 and 11.2, respectively, indicating that the 5 -year risk increased but the lifetime risk stayed the same for the city).

Baghdad, Dhi Qar, Maysan, and Nineveh have the highest 5-year risk, while Najaf, Dhi Qar, Baghdad, and Nineveh have the highest lifetime risk.

Dhi Qar has a very high risk in both cases, so screening programs are especially important in this governorate; however, preventative measures should also be implemented in all.

According to the linear regression model, we found that age, family history, and menopause are the most important predictors for 5-year risk (with smoking playing a role as well), while family history is the most important predictor for lifetime risk.

Comparing data from studies performed in other countries (Table 6), Iraq has the highest breast cancer risk.

Prevention programs are therefore essential to eliminate high risk among Iraqi women, especially when one considers that breast cancer rates are increasing greatly throughout Iraq.

According to the Gail Model, older women have a greater risk of breast cancer-as age increases, the risk of $\mathrm{BC}$ increases. We found this to be true in our results, as risk was highest among the older age groups. This trend is similar to that of nearby countries, as shown in Table 6 . 
Table 4 Risk assessment using the Gail model

\begin{tabular}{|c|c|c|c|c|c|}
\hline & \multicolumn{2}{|l|}{ 5-year risk } & \multicolumn{3}{|l|}{ Lifetime risk } \\
\hline & Low & High & Low & Moderate & High \\
\hline \multicolumn{6}{|c|}{ 1. Are your parents blood relatives? } \\
\hline Yes & $364(44.2 \%)$ & $109(40.3 \%)$ & 295 (41.7\%) & $151(45.7 \%)$ & $27(49 \%)$ \\
\hline No & $455(55.2 \%)$ & $159(59 \%)$ & $409(57.8 \%)$ & $177(53.4 \%)$ & $28(51 \%)$ \\
\hline Unknown & $4(0.6 \%)$ & $2(0.7 \%)$ & $3(0.5 \%)$ & $3(0.9 \%)$ & $(0 \%)$ \\
\hline \multicolumn{6}{|l|}{ 2. Marital status } \\
\hline Yes & $741(90 \%)$ & $265(98 \%)$ & $625(88.4 \%)$ & $327(98.8 \%)$ & $54(98.2 \%)$ \\
\hline No & $82(10 \%)$ & $5(2 \%)$ & $82(11.6 \%)$ & $4(1.2 \%)$ & $(1.8 \%)$ \\
\hline \multicolumn{6}{|l|}{ 3. Educational level } \\
\hline Illiterate & $114(13.8 \%)$ & $97(36 \%)$ & $131(18.5 \%)$ & $73(22 \%)$ & $7(12.8 \%)$ \\
\hline Primary & $191(23.2 \%)$ & $61(22.6 \%)$ & $127(18 \%)$ & $113(34.1 \%)$ & $12(21.8)$ \\
\hline Secondary & $238(29 \%)$ & $55(20.3 \%)$ & $177(25 \%)$ & $98(29.6 \%)$ & $18(32.7 \%)$ \\
\hline University & $280(34 \%)$ & $57(21.1 \%)$ & $272(38.5 \%)$ & $47(14.3 \%)$ & $(32.7 \%)$ \\
\hline \multicolumn{6}{|l|}{ 4. Number of children } \\
\hline No children & $129(15.6 \%)$ & $2(0.7 \%)$ & $130(18.3 \%)$ & $1(0.3 \%)$ & $0(0 \%)$ \\
\hline 1-2 children & $127(15.4 \%)$ & $35(13 \%)$ & $98(13.8 \%)$ & $55(16.6 \%)$ & $9(16.3 \%)$ \\
\hline 3-5 children & $375(45.5 \%)$ & $101(37.4 \%)$ & $303(42.8 \%)$ & $141(42.5 \%)$ & $32(58.1 \%)$ \\
\hline More than 5 & $192(23.5 \%)$ & $132(48.9 \%)$ & $176(25.1 \%)$ & $134(40.6 \%)$ & $(25.6 \%)$ \\
\hline \multicolumn{6}{|l|}{ 5. Age at first live birth } \\
\hline No birth & $128(15.6 \%)$ & $2(0.7 \%)$ & $129(18.2 \%)$ & $1(0.3 \%)$ & $0(0 \%)$ \\
\hline Less than 20 years & $181(22 \%)$ & $165(61 \%)$ & $70(10 \%)$ & $255(77 \%)$ & $21(38.3 \%)$ \\
\hline $20-24$ years & $296(36 \%)$ & $55(20.3 \%)$ & $283(40 \%)$ & $43(13 \%)$ & $25(45.4 \%)$ \\
\hline $25-29$ years & $169(20.5 \%)$ & $26(9.6 \%)$ & $169(24 \%)$ & $18(5.4 \%)$ & $8(14.5 \%)$ \\
\hline $30-39$ years & $47(5.7 \%)$ & $22(8.4 \%)$ & $54(7.6 \%)$ & $14(4.3 \%)$ & $1(1.8 \%)$ \\
\hline More than 40 years & $2(0.2 \%)$ & $0(0 \%)$ & $2(0.2 \%)$ & $0(0 \%)$ & $(0 \%)$ \\
\hline \multicolumn{6}{|l|}{ 6. Breast feeding } \\
\hline Yes & $617(75 \%)$ & $229(84.8 \%)$ & $515(72.9 \%)$ & $289(87.4 \%)$ & $42(76.4 \%)$ \\
\hline No & $206(25 \%)$ & $41(15.2 \%)$ & $192(27.1 \%)$ & $42(12.6 \%)$ & $(23.6 \%)$ \\
\hline \multicolumn{6}{|l|}{ 7. Use of contraceptives } \\
\hline Yes & $424(52.6 \%)$ & $120(44.4 \%)$ & $314(44.4 \%)$ & $201(60.7 \%)$ & $29(52.8 \%)$ \\
\hline No & $399(48.4 \%)$ & $150(55.6 \%)$ & $393(55.6 \%)$ & $130(39.3 \%)$ & $(47.2 \%)$ \\
\hline \multicolumn{6}{|c|}{ 8. Age of menarche (first menstrual cycle) } \\
\hline $7-11$ years & $63(7.7 \%)$ & $50(18.2 \%)$ & $52(7.3 \%)$ & $47(14.1 \%)$ & $14(25.6 \%)$ \\
\hline $12-13$ years & $496(60.2 \%)$ & $175(64.8 \%)$ & $417(59 \%)$ & $219(66.1 \%)$ & $35(63.4 \%)$ \\
\hline More than 13 years & $264(32.1 \%)$ & $45(17 \%)$ & $238(33.7 \%)$ & $65(19.8 \%)$ & $(11 \%)$ \\
\hline \multicolumn{6}{|c|}{ 9. Premenopausal of postmenopausal } \\
\hline Premenopausal & $179(21.7 \%)$ & $173(21 \%)$ & $445(63 \%)$ & $256(77.4 \%)$ & $40(72.8 \%)$ \\
\hline Postmenopausal & $644(78.3 \%)$ & $97(79 \%)$ & $262(37 \%)$ & $75(22.6 \%)$ & $(27.2 \%)$ \\
\hline \multicolumn{6}{|l|}{ 10. Race } \\
\hline Arabic & $665(80.8 \%)$ & $216(80 \%)$ & $564(79.7 \%)$ & $271(82 \%)$ & $46(83.6 \%)$ \\
\hline Kurdish & $99(12 \%)$ & $38(14 \%)$ & $89(12.5 \%)$ & $42(12.6 \%)$ & $6(11 \%)$ \\
\hline Turkmen & $59(7.2 \%)$ & $16(6 \%)$ & $54(7.8 \%)$ & $18(5.4 \%)$ & $(5.4 \%)$ \\
\hline \multicolumn{6}{|l|}{ 11. Monthly income to family } \\
\hline Low (Less than 250 IQD) & $164(20 \%)$ & $60(22 \%)$ & $130(18.5 \%)$ & $81(24.5 \%)$ & $13(23.8 \%)$ \\
\hline Moderate (250-Million IQD) & $459(55.7 \%)$ & $156(58 \%)$ & $385(54.4 \%)$ & $198(59.8 \%)$ & $32(58.1 \%)$ \\
\hline High (More than Million IQD) & $200(24.3 \%)$ & $54(20 \%)$ & $192(27.1 \%)$ & $52(15.7 \%)$ & $(18.1 \%)$ \\
\hline \multicolumn{6}{|c|}{ 12. Smoking (including shisha and vape) } \\
\hline Yes & $32(4 \%)$ & $25(9 \%)$ & $40(5.7 \%)$ & $12(3.7 \%)$ & $5(9 \%)$ \\
\hline No & $791(96 \%)$ & 245 (91\%) & 667 (94.3\%) & 319 (96.3\%) & (91\%) \\
\hline
\end{tabular}


Table 4 (continued)

\begin{tabular}{|c|c|c|c|c|c|}
\hline & \multicolumn{2}{|l|}{ 5-year risk } & \multicolumn{3}{|l|}{ Lifetime risk } \\
\hline & Low & High & Low & Moderate & High \\
\hline \multicolumn{6}{|l|}{ 13. Physical activity } \\
\hline Never & $473(57.4 \%)$ & $175(65 \%)$ & $421(59.5 \%)$ & $201(60.7 \%)$ & $26(47.2 \%)$ \\
\hline Once weekly & $146(17.7 \%)$ & $42(16 \%)$ & $120(17 \%)$ & $58(17.5 \%)$ & $10(18.1 \%)$ \\
\hline Twice weekly & $85(10.4 \%)$ & $31(11 \%)$ & $80(11.3 \%)$ & $25(7.5 \%)$ & $11(20.2 \%)$ \\
\hline More than twice weekly & $119(14.5 \%)$ & $22(8 \%)$ & $86(12.2 \%)$ & $47(14.3 \%)$ & $(14.5 \%)$ \\
\hline \multicolumn{6}{|l|}{ 14. Number of biopsies } \\
\hline No biopsy & $804(97.7 \%)$ & $254(94 \%)$ & $16(2.3 \%)$ & $13(4 \%)$ & $6(11 \%)$ \\
\hline One biopsy (Without hyperplasia) & $19(2.3 \%)$ & $16(6 \%)$ & $691(97.7 \%)$ & $318(96 \%)$ & $(39 \%)$ \\
\hline \multicolumn{6}{|c|}{ 15. Number of first-degree relatives with breast cancer } \\
\hline No one & $745(90.5 \%)$ & $162(60 \%)$ & $670(94.7 \%)$ & $235(71 \%)$ & $2(3.7 \%)$ \\
\hline One relative & $68(8.25 \%)$ & $52(19.25 \%)$ & $31(4.3 \%)$ & $88(26.5)$ & $1(1.8 \%)$ \\
\hline More than one relative & $10(1.25 \%)$ & $56(20.75 \%)$ & $6(1 \%)$ & $8(2.5 \%)$ & $52(94.5 \%)$ \\
\hline
\end{tabular}

Table 5 Linear regression results for the 5-year and lifetime risks

\begin{tabular}{|c|c|c|c|c|}
\hline & R-value & $\mathrm{R}^{2}$-value (\%) & Standard error & $P$ value \\
\hline \multicolumn{5}{|l|}{ 5-year risk } \\
\hline Age & 0.615 & 37.8 & 0.8156 & $<0.001$ \\
\hline Age of menarche & 0.23 & 5.3 & 1.0065 & $<0.001$ \\
\hline Age at first birth & 0.027 & 0.1 & 1.03387 & 0.369 \\
\hline Number of biopsies & 0.124 & 1.5 & 1.02626 & $<0.001$ \\
\hline Race & 0.013 & 0 & 1.03417 & 0.676 \\
\hline First degree relatives & 0.546 & 29.8 & 0.8666 & $<0.001$ \\
\hline Menopause & 0.459 & 21.1 & 0.9189 & $<0.001$ \\
\hline $\begin{array}{l}\text { Using of contracep- } \\
\text { tives }\end{array}$ & 0.044 & 0.2 & 1.033253 & 0.145 \\
\hline Monthly income & 0.025 & 0.1 & 1.03393 & 0.406 \\
\hline Smoking & 0.158 & 2.5 & 1.021231 & 0 \\
\hline Physical activity & 0.055 & 0.3 & 1.032702 & 0.07 \\
\hline \multicolumn{5}{|l|}{ Lifetime risk } \\
\hline Age & 0.336 & 11.3 & 6.4536 & 0 \\
\hline Age of menarche & 0.202 & 4.1 & 6.7098 & 0.003 \\
\hline Age at first birth & 0.177 & 3.1 & 6.7427 & 0.01 \\
\hline Number of biopsies & 0.002 & 0 & 6.851421 & 0.978 \\
\hline Race & 0.047 & 0.2 & 6.84376 & 0.497 \\
\hline First degree relatives & 0.753 & 56.8 & 4.50556 & 0 \\
\hline Menopause & 0.280 & 7.8 & 6.57707 & 0 \\
\hline $\begin{array}{l}\text { Using of contracep- } \\
\text { tives }\end{array}$ & 0.065 & 0.4 & 6.83704 & 0.353 \\
\hline Monthly income & 0.081 & 0.7 & 6.828912 & 0.245 \\
\hline Smoking & 0.079 & 0.6 & 6.829924 & 0.256 \\
\hline Physical activity & 0.067 & 0.4 & 6.836088 & 0.337 \\
\hline
\end{tabular}

We found that Iraq has the greatest risk of breast cancer among all countries, which may be due to the sociopolitical circumstances of the country (chemical warfare,
Table 6 Gail's breast cancer risk in various countries

\begin{tabular}{|c|c|c|c|c|c|}
\hline Country & Year & Sample size & Age & 5-year risk & Lifetime risk \\
\hline USA [13] & 1989 & 4496 & $>50$ & 1.02 & 11.21 \\
\hline USA [17] & 2001 & 319 & $\geq 35$ & 1.67 & - \\
\hline USA [18] & 2004 & 254 & $>40$ & 1.5 & 8.4 \\
\hline USA [19] & 2005 & 8388 & $>18$ & 0.8 & 8 \\
\hline USA [20] & 2006 & 99 & $\geq 35$ & 4.13 & 23.5 \\
\hline USA [21] & 2009 & 883 & $>40$ & 0.88 & - \\
\hline USA [22] & 2016 & 124 & $>50$ & 1.67 & - \\
\hline $\begin{array}{l}\text { Iraq (Baghdad) } \\
\text { [23] }\end{array}$ & 2016 & 250 & $\geq 35$ & 0.95 & 11.3 \\
\hline Iraq (This Study) & 2019 & 1093 & $\geq 35$ & 1.33 & 13.36 \\
\hline Iran [24] & 2008 & 2000 & $\geq 35$ & 0.92 & 9.14 \\
\hline Iran [25] & 2012 & 314 & $\geq 35$ & 0.8 & 9 \\
\hline Iran [26] & 2016 & 560 & $\geq 35$ & 0.6 & 8.9 \\
\hline Iran [27] & 2016 & 3847 & $\geq 35$ & 1.61 & 11.71 \\
\hline Turkey [28] & 2010 & 650 & $\geq 35$ & 1.67 & 7.7 \\
\hline Turkey [29] & 2011 & 415 & $>20$ & 1.7 & 15 \\
\hline Turkey [15] & 2015 & 231 & $\geq 35$ & 0.88 & 9.37 \\
\hline $\begin{array}{l}\text { United King- } \\
\text { dom [15] }\end{array}$ & 2013 & 355 & $>46$ & 1.5 & 9 \\
\hline Bulgaria [31] & 2009 & 315 & $\geq 35$ & 1.51 & - \\
\hline India [32] & 2013 & 200 & $\geq 35$ & - & 7.8 \\
\hline Korea [33] & 2013 & 3789 & $<50$ & 0.44 & 2.24 \\
\hline $\begin{array}{l}\text { Czech Republic } \\
{[34]}\end{array}$ & 2006 & 4598 & $\geq 35$ & 1.37 & 8.02 \\
\hline Qatar [24] & 2016 & 1488 & $\geq 35$ & 1.12 & 10.57 \\
\hline $\begin{array}{l}\text { Saudi Arabia } \\
\text { [35] }\end{array}$ & 2017 & 180 & $\geq 35$ & 0.87 & 9.6 \\
\hline Bahrain [36] & 2013 & 300 & $\geq 35$ & 0.7 & 9.3 \\
\hline
\end{tabular}

bombings, etc.). This is likely why we see higher $\mathrm{BC}$ risk in the southern governorates such as Basra and Thi Qar, 


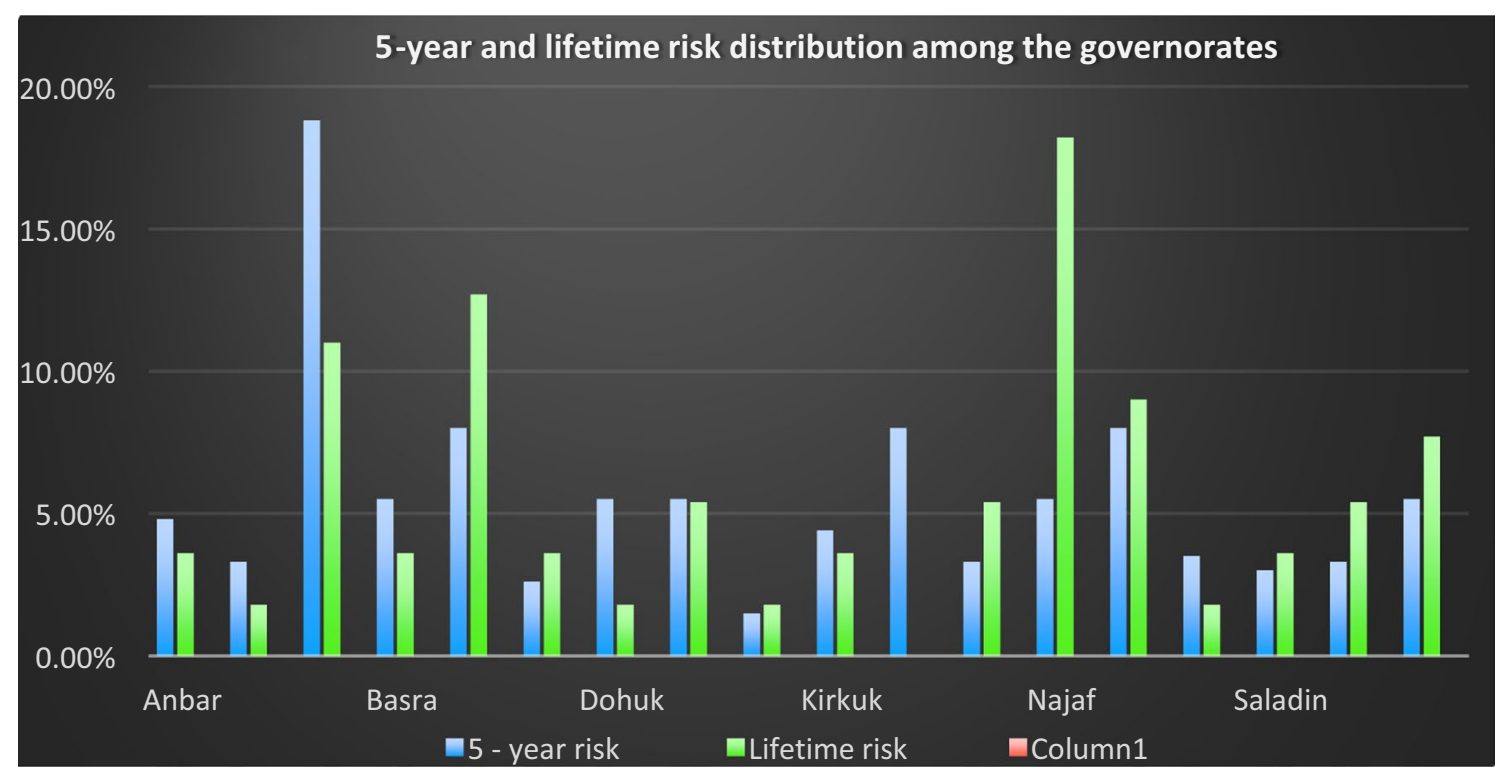

Fig. 15 -year and lifetime risk distribution among the governorates

since these regions have historically been more prone to wars than the others (particularly in 1991 and 2003, when the wars were at their peak).

Women who take contraceptive pills should be aware of the fact that they are predisposed to breast cancer, according to the Gail Model and based on the results of our study. In addition, our study corrobated the association from previous studies that found women who do not breast feed their children are at a higher risk for BC.

We found women with a family history of breast cancer are at increased risk of developing breast cancer compared to women with no family history of breast cancer and recommend these women perform regular checks on themselves as a preventative measure. Moreover, there was no statistical difference in the effect of age on the demographic and clinical profiles of breast cancer among premenopausal versus postmenopausal Iraqi patients after controlling for marital status, level of education, and number of parities.

In Iraq, a significant proportion of breast cancer patients have a locally advanced disease at the time of diagnosis. To reinforce our national early detection program, it is essential to encourage public awareness through educational campaigns.

Screening programs and educational campaigns that teach Iraqi women to check their breasts regularly are crucial to limit this type of cancer. Considering that Iraq has a poor healthcare system and that many patients are deprived of high-quality care, it is imperative that preventative measures be discussed in order to reduce the incidence of breast cancer in the population [30].

\section{Limitations}

It is worth mentioning the limitations that were observed while conducting this study. Chiefly, the Gail Model is calibrated to the United States' population of women, and due to many variables, risk calculations might not be consistent for Iraqi women. Moreover, problems were encountered with sample randomization, since some women refused to participate, and some others had already been diagnosed with breast cancer.

\section{Conclusion}

Breast cancer is a wide-spreading problem in the world and particularly in Iraq.

The Gail Model estimates the risk of developing breast cancer in any population, depending on its variables. The 5-year risk of BC among Iraqi women in 2019 was found to be distributed chiefly between Baghdad, Dhi Qar, Nineveh, and Maysan, with the greatest lifetime risk in Najaf and Dhi Qar. Screening programs are considered essential and heavily recommended in the process of breast cancer control and prevention. Prevention programs need to be implemented and awareness campaigns organized in order to highlight the importance of early detection and treatment to improve survival.

\section{Abbreviations}

BC: Breast cancer; BCRAT: Breast Cancer Risk Assessment Tool; BRCA: Breast cancer gene.

\section{Acknowledgements}

We want to thank the people who helped us in our research and in collecting the data from all of the 18 governorates of Iraq: Dr. Shimaa Kadhim (the 
supervisor), Mohammed Tariq, Mina Abdul-Kareem, Wa'el Ali, Mohammed Inhab, Saleh Abdul-Kareem, Maher Abdul-Basset, Aziz Mohammed, Salam Abu Jehad, Ali Muhson, Salma Muhson, Jawaher Mutar, Talib Hashim, Ahmed Ramadhan, Dhafer Sattar, Intisar K., Shahzana Mohammed, Salah Ali Rasheed, and Seham Fadhel.

\section{Authors' contributions}

$\mathrm{HTH}, \mathrm{MAH}$, and KMT wrote the manuscript, analyzed the data, and conducted the survey, while JB and AE revised, reviewed and edited the final version. All authors read and approved the final manuscript.

\section{Funding}

We declare that we have not received any source of funding.

\section{Availability of data and materials}

The dataset can be obtained from the corresponding author upon reasonable request.

\section{Declarations}

\section{Ethics approval and consent to participate}

Ethical approval was obtained from the ethical committee of the University of Baghdad - College of Medicine. All methods were carried out in accordance with relevant guidelines and regulations. Informed consents were obtained from all the participants. If the participants are illiterate, we obtained the informed consents from their legally authorized representatives.

\section{Consent for publication}

Not applicable.

\section{Competing interests}

We declare that we have no conflicts of interest.

\section{Author details}

${ }^{1}$ University of Baghdad, College of Medicine, Baghdad, Iraq. ${ }^{2}$ Faculty of Medicine, Tishreen University, Latakia, Syria. ${ }^{3}$ Faculty of Medical Sciences, Lebanese University, Hadath, Beirut, Lebanon. ${ }^{4}$ College of Medicine, Drexel University, Philadelphia, USA.

Received: 3 March 2021 Accepted: 1 December 2021 Published online: 15 December 2021

\section{References}

1. Gibberd R. Globocan 1: cancer incidence and mortality worldwide. J. Ferlay, D.M. Parkin and P. Pisani, IARC Press, Lyon, 1999. Price: \$90. Stat Med. 2000;19(19):2714-5.

2. [Internet]. 2021 [cited 18 May 2021]. https://www.who.int/news-room/ fact-sheets/detail/cancer.index.html

3. Abdalzahra RN, Ali RM. Burdens of breast cancer upon women's psychological health at Oncology Hospitals in Baghdad City. Iraqi J Public Health. 2017;1:15-9.

4. Zuhair A, Khudyair R, Abdulsamad R. Analyze predisposing risk factor of breast cancer (BC) among Iraqi women in Baghdad teaching hospital and oncology unit center in Baghdad. Baghdad Med J Stud. 2020;1(1):9-12.

5. Ferlay J, Soerjomataram I, Dikshit R, Eser S, Mathers C, Rebelo M, Parkin DM, Forman D, Bray F. Cancer incidence and mortality worldwide: Sources, methods and major patterns in GLOBOCAN 2012. Int J Cancer. 2015;136:E359-86.

6. Bray F, Ferlay J, Soerjomataram I, Siegel RL, Torre LA, Jemal A. Global cancer statistics 2018: GLOBOCAN estimates of incidence and mortality worldwide for 36 cancers in 185 countries. CA Cancer J Clin. 2018:68(6):394-424

7. Oeffinger KC, Fontham ET, Etzioni R, Herzig A, Michaelson JS, Shih YC, Walter LC, Church TR, Flowers CR, LaMonte SJ, Wolf AM, DeSantis C, Lortet-Tieulent J, Andrews K, Manassaram-Baptiste D, Saslow D, Smith RA, Brawley OW, Wender R, American Cancer Society. Breast cancer screening for women at average risk: 2015 guideline update from the American Cancer Society. JAMA. 2015;314(15):1599-614.
8. Saslow D, Boetes C, Burke W, Harms S, Leach MO, Lehman CD, Morris E, Pisano E, Schnall M, Sener S, Smith RA, Warner E, Yaffe M, Andrews KS, Russell CA, American Cancer Society Breast Cancer Advisory Group. American Cancer Society guidelines for breast screening with MRI as an adjunct to mammography. CA Cancer J Clin. 2007;57(2):75-89.

9. McTiernan A, Kuniyuki A, Yasui Y, Bowen D, Burke W, Culver JB, Anderson R, Durfy S. Comparisons of two breast cancer risk estimates in women with a family history of breast cancer. Cancer Epidemiol Biomark Prev. 2001;10(4):333-8.

10. Bondy Melissa $L$, et al. Validation of a breast cancer risk assessment model in women with a positive family history. JNCI J Natl Cancer Inst. 1994;86(8):620-5.

11. Gail MH, Mai PL. Comparing breast cancer risk assessment models. JNCI J Natl Cancer Inst. 2010;102(10):665-8.

12. Armstrong K, Eisen A, Weber B. Assessing the risk of breast cancer. N Engl J Med. 2000;342(8):564-71.

13. Gail MH, Brinton LA, Byar DP, Corle DK, Green SB, Schairer C, Mulvihill JJ. Projecting individualized probabilities of developing breast cancer for white females who are being examined annually. J Natl Cancer Inst. 1989:81(24):1879-86.

14. World Population Clock: 7.9 Billion People. Worldometer [Internet]. Worldometers.info. 2021. Cited 18 May 2021. https://www.worldomete rs.info/world-population/.

15. Eadie L, Enfield L, Taylor P, Michell M, Gibson A. Breast cancer risk scores in a standard screening population. Breast Cancer Manag. 2013;6:463-79.

16. Costantino JP, Gail MH, Pee D, Anderson S, Redmond CK, Benichou J, Wieand HS. Validation studies for models projecting the risk of invasive and total breast cancer incidence. JNCI J Natl Cancer Inst. 1999;91(18):1541-8.

17. Abu-Rustum NR, Herbolsheimer $\mathrm{H}$. Breast cancer risk assessment in indigent women at a public hospital. Gynecol Oncol. 2001;81(2):287-90.

18. Davids SL, Schapira MM, McAuliffe TL, Nattinger AB. Predictors of pessimistic breast cancer risk perceptions in a primary care population. J Gen Intern Med. 2004;19(4):310-5.

19. Tice JA, Cummings SR, Ziv E, Kerlikowske K. Mammographic breast density and the Gail model for breast cancer risk prediction in a screening population. Breast Cancer Res Treat. 2005:94(2):115-22.

20. Palomares MR, Machia JR, Lehman CD, Daling JR, McTiernan A. Mammographic density correlation with Gail model breast cancer risk estimates and component risk factors. Cancer Epidemiol Biomark Prev. 2006:15(7):1324-30

21. Adams-Campbell LL, Makambi KH, Frederick WA, Gaskins M, DeWitty RL, McCaskill-Stevens W. Breast cancer risk assessments comparing Gail and CARE models in African American women. Breast J. 2009;15(suppl 1):S72-5.

22. Khaliq W, Jelovac D, Wright SM. Prevalence of chemopreventive agent use among hospitalised women at high risk for breast cancer: a crosssectional study. BMJ Open. 2016;6(11):e012550.

23. Ewaid SH, Al-Azzawi LHA. Breast cancer risk assessment by Gail Model in women of Baghdad. Alex J Med. 2016:53(2):183-6.

24. Bener A, Çatan F, El Ayoubi HR, Acar A, Ibrahim WH. Assessing breast cancer risk estimates based on the Gail Model and its predictors in Qatari women. J Prim Care Community Health. 2017;8(3):180-7.

25. Seyednoori T, Pakseresht S, Roushan Z. Risk of developing breast cancer by utilizing Gail model. Women Health. 2012;52(4):391-402.

26. Mirghafourvand M, Mohammad-Alizadeh-Charandabi S, Ahmadpour P, Rahi P. Breast cancer risk based on the Gail Model and its predictors in Iranian women. Asian Pac J Cancer Prev : APJCP. 2016;17(8):3741-5.

27. Khazaee-Pool M, Majlessi F, Nedjat S, Montazeri A, Janani L, Pashaei T. Assessing breast cancer risk among iranian women using the Gail model. Asian Pac J Cancer Prev: APJCP. 2016:17(8):3759-62.

28. Ulusoy C, Kepenekci I, Kose K, Aydintug S, Cam R. Applicability of the Gail model for breast cancer risk assessment in Turkish female population and evaluation of breastfeeding as a risk factor. Breast Cancer Res Treat. 2010:120(2):419-24.

29. Yilmaz M, Guler G, Bekar M, Guler N. Risk of breast cancer, health beliefs and screening behaviour among Turkish academic women and housewives. Asian Pac J Cancer Prev: APJCP. 2011;12(3):817-22. 
30. Erbil N, Dundar N, Inan C, Bolukbas N. Breast cancer risk assessment using the Gail model: a Turkish study. Asian Pac J Cancer Prev: APJCP. 2015;16(1):303-6.

31. Baitchev G, Christova P, Ivanov I. Is the Gail model for breast cancer risk assessment valid for the Bulgarian women? Khirurgiia. 2009;6:27-30.

32. Challa VR, Swamyvelu K, Shetty N. Assessment of the clinical utility of the Gail model in estimating the risk of breast cancer in women from the Indian population. Ecancermedicalscience. 2013;7:363.

33. Park B, Ma SH, Shin A, Chang MC, Choi JY, Kim S, Han W, Noh DY, Ahn SH, Kang D, Yoo KY, Park SK. Korean risk assessment model for breast cancer risk prediction. PLOS ONE. 2013;8(10):e76736.

34. Novotny J, Pecen L, Petruzelka L, Svobodnik A, Dusek L, Danes J, Skovajsova M. Breast cancer risk assessment in the Czech female population-an adjustment of the original Gail model. Breast Cancer Res Treat. 2006;95(1):29-35.

35. Al Otaibi H. Breast cancer risk assessment using the Gail Model and it's predictors in Saudi women. Asian Pac J Cancer Prev. 2017;18(11):2971-5.

36. Fikree M, Hamadeh R, Oxon P. Breast cancer knowledge among Bahraini women attending primary health care centers. Bahrain Med Bull. 2011:33:1-8.

\section{Publisher's Note}

Springer Nature remains neutral with regard to jurisdictional claims in published maps and institutional affiliations.

- fast, convenient online submission

- thorough peer review by experienced researchers in your field

- rapid publication on acceptance

- support for research data, including large and complex data types

- gold Open Access which fosters wider collaboration and increased citations

- maximum visibility for your research: over $100 \mathrm{M}$ website views per year

At $\mathrm{BMC}$, research is always in progress.

Learn more biomedcentral.com/submissions 